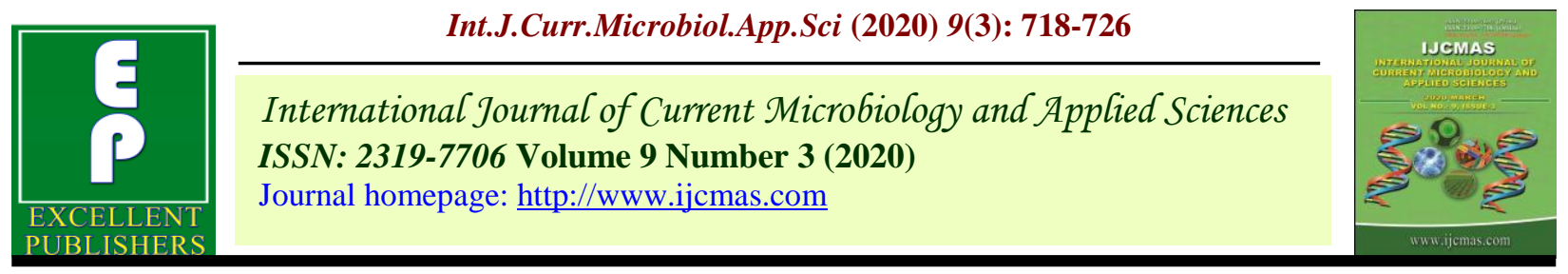

Original Research Article

https://doi.org/10.20546/ijcmas.2020.903.086

\title{
Field Evaluation of Native Pink Pigmented Facultative Methylotrophs for Growth Promotion and Anthracnose Management in Chilli
}

\author{
Savitha Santosh ${ }^{1,2 *}$ and M. N. Sreenivasa ${ }^{2}$ \\ ${ }^{1}$ ICAR - Central Institute for Cotton Research (CICR), Nagpur, Maharashtra - 440010, India \\ ${ }^{2}$ Department of Agricultural Microbiology, University of Agricultural Sciences (UAS), \\ Dharwad, Karnataka - 580005, India \\ *Corresponding author
}

\begin{abstract}
A B S T R A C T
Keywords

PPFM, Chilli,

Anthracnose,

Growth

promotion

Article Info

Accepted:

05 February 2020

Available Online:

10 March 2020

Field studies were conducted to study the role of native pink pigmented facultative methylotrophs (PPFMs) in plant growth promotion and anthracnose management in chilli. The efficient PPFM isolates were identified for field evaluation upon in-vitro functional characterization. Three selected isolates (PPFM6, PPFM170 and PPFM35) along with their consortium, the reference strain of PPFM (Methylobacterium extorquens AM1), chemical control (carbendazim) were included in field experiment. Increased plant height, dry matter and chlorophyll content were recorded with inoculation of PPFM isolates at different crop stages. Reduction in anthracnose incidence and higher yield levels along with improved capsaicin content of chilli was observed with inoculation of PPFM over uninoculated control. Chemical control recorded least disease incidence and yielded more chilli compared to PPFM isolates. The study clearly establishes PPFM's as plant growth promoters of chilli having remarkable biocontrol efficiency against $C$. capsici.
\end{abstract}

\section{Introduction}

Chilli (Capsicum annum L.) is cultivated throughout the world for its pungency, colour, flavour and aroma and is a key component of our Indian cuisine, without which food is considered unfinished. Among many production constraints of chilli, diseases caused by fungi, bacteria, viruses, nematodes inflict major crop losses worldwide, limiting its productivity. Chilli anthracnose caused by Colletotrichum spp. alone accounts for 10$54 \%$ yield losses in India (Lakshmesha et al., 2005; Ramachandran and Rathnamma, 2006). Management of anthracnose is imperative to increase productivity of chilli as it affects the economic part. Though, large numbers of agrochemicals are commercialized for plant 
growth promotion and effective anthracnose management in chilli, but environmentally and economically, they are not benign. In addition, they enhance resistance development in pathogens and reduce beneficial microflora population. Therefore, biological approaches using rhizosphere and phyllosphere microorganisms are considered as viable alternative for sustainable chilli production.

The biocontrol agents against Colletotrichum sp. which play significant role in anthracnose management include strains of Trichoderma, Pseudomonas and Bacillus etc. Considerable number of bacterial species, mostly associated with the plant rhizosphere have been evaluated and found to be beneficial for plant growth, yield enhancement and quality improvement (Pyrlak and Kose, 2009). Studies to explore phyllosphere bioagents as plant growth promoters and biocontrol agents are very sparse. Among phyllosphere microorganisms, members of pink pigmented facultatvite methylotrophs (PPFM) potentially dominate the phyllosphere population. Diverse association of PPFM with plants are reported from free-living to epiphytic, endophytic and symbiotic forms (Sy et al., 2001; Jackson et al., 2006). Therefore, methylotrophs have received a great attention in the recent times due to their abundance in the biosphere and their potential commercial applications.

PPFMs are known to improve plant growth (Radha et al., 2009, Kim et al., 2010; Yim et al., 2012., Savitha et al., 2013, 2019) with remarkable biocontrol activity against plant pathogens (Madhaiyan et al., 2004, 2006; Indiragandhi et al., 2008., Janahiraman et al., 2016). However, the native isolated strains are seldom evaluated for growth promotion and yield enhancement. Hitherto, to the best of our knowledge, there are no reports on field evaluation of native PPFM for management of chilli anthracnose. To address this knowledge gap, a study was planned to understand the role of native PPFMs in plant growth promotion and management of chilli anthracnose.

\section{Materials and Methods}

A field experiment was conducted with randomised block design comprising seven treatments and three replications to assess the effect of three selected isolates of PPFM (PPFM6, PPFM170 and PPFM35), their consortia (PPFM6+PPFM170+PPFM35; here after referred as PPFM consortia) and reference strain (Methylobacterium extorquens AM 1) on growth, yield and anthracnose incidence in chilli. Chemical control (carbendazim) and uninoculated control served as checks. The chilli (variety Byadagi dabbi) seedlings were raised in the nursery bed of size $1 \mathrm{~m} \times 1 \mathrm{~m}$. The recommended packages of practises were followed to raise the healthy seedlings. The 45 days old chilli seedlings were uprooted from nursery and transplanted in field.

\section{PPFM inoculum and its inoculation}

The isolated strains of PPFM from disease free chilli plants in anthracnose infected fields were functionally characterised for plant growth promotional ability viz., IAA, GA and cytokinin production, biocontrol efficiency against major pathogens of chilli under in vitro conditions (Savitha et al., 2013, 2015 and 2019). Based on in-vitro studies, three isolates were selected for field evaluation. The 72 hours old, log phase PPFM culture in ammonium mineral salts (AMS) broth was used for further mass multiplication of bioinoculant. The flasks were kept in a temperature controlled shaker at $28 \pm 2^{0} \mathrm{C}$ for 5 days to get a population of $10^{9} \mathrm{cfu} / \mathrm{ml}$ of liquid culture. Preparation of carrier based bioinoculant was achieved by mixing broth 
culture with sterilized lignite powder at 1:3 ratio using which seed treatment was carried out. One $\mathrm{kg}$ carrier based inoculant was mixed with 15 litre of sterilized distilled water was used for seedling dip. The seedlings were dipped in the slurry for $30 \mathrm{~min}$ before transplanting. The spraying inoculum was diluted at $1: 1$ ratio with sterilized distilled water and sprayed with a hand sprayer at the rate of $25 \mathrm{ml} /$ plant on the leaves in the morning hours to achieve uniform wetting (Holland and Polacco, 1994) at 30, 45 and 60 days after transplanting (DAT).

\section{Plant parameters, microbial population and disease intensity}

The plant growth indicators like height of the plant and chlorophyll content were recorded at 30, 60, 90 and 130 DAT. Estimation of capsaicin content was done by colorimetric method (Mahadevan and Sridhar, 1986). The population of PPFM on rhizosphere and phyllosphere at different intervals was enumerated by serial dilution and plating technique. The colonies appearing on plates after 72 hours of incubation were counted and expressed as number of $\mathrm{cfu} / \mathrm{g}$ sample. The total dry matter was measured at the time of harvesting (130 DAT) by oven drying samples at $70^{\circ} \mathrm{C}$ till constant weight is achieved. The anthracnose incidence was recorded by scoring five plants in each replication using 0-9 scale (Mayee and Datar, 1986). Per cent disease index (PDI) was calculated with the disease scales as per Wheeler (1969) while, per cent fruit rot infection (FRI) was calculated by dividing number of infected fruits by total number of fruits observed.

\section{Statistical analysis}

The data pertaining to plant growth promotional ability and biocontrol activity of different PPFM isolates were subjected for statistical analysis by following the appropriate statistical procedures (Panse and Sukhatme, 1985). The values of $P<0.05$ were considered as statistically significant. Percentage values of FRI, PDI and capsaicin content were arc-sin transformed before statistical analysis (Gomez and Gomez, 1984). PPFM population in rhizosphere and phyllosphere values were log-transformed before subjecting to ANOVA.

\section{Results and Discussion}

\section{Influence of PPFM isolates on plant growth parameters}

Inoculation of different PPFM isolates showed an increase in plant growth compared to uninoculated control. Plant height in different treatments was recorded at 30, 60, 90 and 130 DAT (Table 1). The maximum plant height was recorded with inoculation of PPFM6 $(26.32 \mathrm{~cm})$ followed by PPFM consortia $(26.00 \mathrm{~cm})$. Chemical control $(22.35 \mathrm{~cm})$ and uninoculated control $(22.00$ $\mathrm{cm})$ showed significantly lesser plant height. Similar trend was observed for plant height by different treatments at 60DAT, 90DAT and 130DAT. Plant biomass (total dry matter content) recorded at 130DAT showed significant increase with treatments PPFM consortia (90.25g) and PPFM6(90.00g). The least biomass was recorded in uninoculated control (72.00 g). Chlorophyll content, a vital photosynthetic element of plants at 30 DAT was found to be high in treatments with PPFM consortia (26.50 SPAD) followed by PPFM6 (26.00 SPAD) (Table 2) while, the chemical control (22.00 SPAD value) and uninoculated control (22.00 SPAD value) recorded least chlorophyll content. Similar trend of chlorophyll content was observed with different treatments at 60DAT, 90DAT and 130DAT. The inoculation of PPFM to chilli plants significantly increased plant height, total biomass and chlorophyll content 
as compared to uninoculated plants. These findings were validated in other crops as well including cotton (Madhaiyan et al., 2005), rice (Senthilkumar, 2003), groundnut (Reddy, 2002), tomato (Thangamani and Sundaram, 2005). Reduction in chlorophyll content of plants was observed in anthracnose infected plants and it may be attributed to toxic effect of the pathogen (Muthuchelian et al., 1990).
Pathogen is known to initiate leaf chlorosis by producing chlorophyllase enzyme and eventually necrosis condition in the phylloplane, thus reducing the number and size of the chloroplasts. PPFM may be involved in suppressing chlorophyllase activity or they produce the needed organic acids for the host growth and development.

Table.1 Influence of PPFM isolates on plant height and total dry weight of chilli under field condition

\begin{tabular}{|c|c|c|c|c|c|}
\hline \multirow[t]{2}{*}{ Treatment details } & \multicolumn{4}{|c|}{$\begin{array}{c}\text { Plant Height }(\mathbf{c m}) \\
\text { DAT }\end{array}$} & \multirow[t]{2}{*}{$\begin{array}{c}\text { Total dry matter (g/plant) at } 130 \\
\text { DAT }\end{array}$} \\
\hline & 30 & 60 & 90 & 130 & \\
\hline PPFM 6 & 26.32 & 43.95 & 60.15 & 71.15 & 90.00 \\
\hline PPFM 170 & 24.60 & 42.00 & 58.50 & 69.50 & 87.28 \\
\hline PPFM 35 & 23.50 & 41.10 & 58.00 & 69.00 & 86.15 \\
\hline PPFM Consortia & 26.00 & 44.15 & 60.50 & 71.70 & 90.25 \\
\hline $\begin{array}{l}\text { Reference strain of PPFM } \\
\text { (M. extorquens AM 1) }\end{array}$ & 23.50 & 40.00 & 56.50 & 67.60 & 85.80 \\
\hline Chemical control (carbendazim) & 22.35 & 37.70 & 55.50 & 67.50 & 82.00 \\
\hline Uninoculated control & 22.00 & 36.00 & 51.00 & 57.00 & 72.00 \\
\hline S. Em \pm & 0.33 & 0.34 & 0.46 & 0.53 & 0.35 \\
\hline $\mathrm{CD}(\mathbf{0 . 0 5})$ & 1.03 & 1.06 & 1.42 & 1.62 & 1.09 \\
\hline
\end{tabular}

Table.2 Influence of PPFM isolates on chlorophyll content of chilli under field condition

\begin{tabular}{|l|c|c|c|c|}
\hline \multicolumn{1}{|c|}{ Treatment details } & \multicolumn{4}{c|}{ Chlorophyll content (SPAD value) } \\
\hline & 30 & 60 & 90 & 130 \\
\hline PPFM 6 & 26.00 & 40.00 & 33.00 & 26.80 \\
\hline PFM 170 & 24.50 & 37.50 & 31.28 & 24.00 \\
\hline PPFM 35 & 24.00 & 36.00 & 30.00 & 22.50 \\
\hline PPFM Consortia & 26.50 & 40.20 & 33.25 & 27.00 \\
\hline Reference strain of PPFM (M. extorquens AM 1) & 24.00 & 35.80 & 30.00 & 22.50 \\
\hline Chemical control (carbendazim) & 22.00 & 34.00 & 30.00 & 22.50 \\
\hline Uninoculated control & 22.00 & 32.00 & 26.00 & 18.00 \\
\hline S.Em \pm & 0.37 & 0.45 & 0.39 & 0.44 \\
\hline CD (0.05) & 1.14 & 1.40 & 1.20 & 1.35 \\
\hline Note: DAT- Days after transplanting & & & & \\
\hline
\end{tabular}


Table.3 Population dynamics of PPFMs at different stages of chilli growth under field condition

\begin{tabular}{|c|c|c|c|c|c|c|c|c|}
\hline \multirow[t]{2}{*}{ Treatment details } & \multicolumn{4}{|c|}{$\begin{array}{c}\text { Population of PPFM in rhizosphere } \\
\left(10^{4} \text { cfu/g soil }\right) \\
\text { DAT }\end{array}$} & \multicolumn{4}{|c|}{$\begin{array}{c}\text { Population of PPFM in phyllosphere } \\
\left(10^{4} \mathrm{cfu} / \mathrm{g} \text { leaf }\right. \\
\text { DAT }\end{array}$} \\
\hline & 30 & 60 & 90 & 130 & 30 & 60 & 90 & 130 \\
\hline PPFM 6 & $\begin{array}{l}13.13 \\
(5.12)\end{array}$ & $\begin{array}{l}14.15 \\
(5.15)\end{array}$ & $\begin{array}{l}14.75 \\
(5.17)\end{array}$ & $\begin{array}{c}8.22 \\
(4.91)\end{array}$ & $\begin{array}{l}34.12 \\
(5.53)\end{array}$ & $\begin{array}{l}42.32 \\
(5.63)\end{array}$ & $\begin{array}{l}45.27 \\
(5.66)\end{array}$ & $\begin{array}{l}37.85 \\
(5.58)\end{array}$ \\
\hline PPFM 170 & $\begin{array}{l}12.17 \\
(5.08)\end{array}$ & $\begin{array}{l}12.50 \\
(5.09)\end{array}$ & $\begin{array}{l}13.13 \\
(5.12)\end{array}$ & $\begin{array}{c}7.00 \\
(4.84)\end{array}$ & $\begin{array}{l}33.31 \\
(5.52)\end{array}$ & $\begin{array}{l}41.25 \\
(5.62)\end{array}$ & $\begin{array}{l}44.30 \\
(5.65)\end{array}$ & $\begin{array}{l}36.28 \\
(5.56)\end{array}$ \\
\hline PPFM 35 & $\begin{array}{l}10.32 \\
(5.01)\end{array}$ & $\begin{array}{l}11.50 \\
(5.06)\end{array}$ & $\begin{array}{l}12.53 \\
(5.10)\end{array}$ & $\begin{array}{c}6.98 \\
(4.84)\end{array}$ & $\begin{array}{l}32.18 \\
(5.51)\end{array}$ & $\begin{array}{l}40.21 \\
(5.60)\end{array}$ & $\begin{array}{l}42.30 \\
(5.63)\end{array}$ & $\begin{array}{l}35.92 \\
(5.56)\end{array}$ \\
\hline PPFM Consortia & $\begin{array}{l}13.00 \\
(5.11)\end{array}$ & $\begin{array}{l}14.52 \\
(5.16)\end{array}$ & $\begin{array}{l}15.15 \\
(5.18)\end{array}$ & $\begin{array}{c}8.93 \\
(4.95)\end{array}$ & $\begin{array}{l}35.42 \\
(5.55)\end{array}$ & $\begin{array}{l}43.13 \\
(5.63)\end{array}$ & $\begin{array}{l}46.18 \\
(5.66)\end{array}$ & $\begin{array}{l}38.48 \\
(5.59)\end{array}$ \\
\hline $\begin{array}{l}\text { Reference strain of PPFM } \\
\text { (M. extorquens AM 1) }\end{array}$ & $\begin{array}{l}11.33 \\
(5.05)\end{array}$ & $\begin{array}{l}12.32 \\
(5.09)\end{array}$ & $\begin{array}{l}13.15 \\
(5.12)\end{array}$ & $\begin{array}{c}7.43 \\
(4.87)\end{array}$ & $\begin{array}{l}32.18 \\
(5.51)\end{array}$ & $\begin{array}{l}39.48 \\
(5.60)\end{array}$ & $\begin{array}{l}40.56 \\
(5.61)\end{array}$ & $\begin{array}{l}34.56 \\
(5.54)\end{array}$ \\
\hline $\begin{array}{l}\text { Chemical } \\
\text { (carbendazim) }\end{array}$ & $\begin{array}{c}5.60 \\
(4.75)\end{array}$ & $\begin{array}{c}5.92 \\
(4.77)\end{array}$ & $\begin{array}{c}6.40 \\
(4.81)\end{array}$ & $\begin{array}{c}5.85 \\
(4.77)\end{array}$ & $\begin{array}{l}16.10 \\
(5.21)\end{array}$ & $\begin{array}{l}21.40 \\
(5.33)\end{array}$ & $\begin{array}{l}21.80 \\
(5.34)\end{array}$ & $\begin{array}{l}14.80 \\
(5.17)\end{array}$ \\
\hline Uninoculated control & $\begin{array}{c}5.60 \\
(4.75)\end{array}$ & $\begin{array}{c}5.80 \\
(4.76)\end{array}$ & $\begin{array}{c}6.10 \\
(4.79)\end{array}$ & $\begin{array}{c}5.25 \\
(4.72)\end{array}$ & $\begin{array}{l}16.00 \\
(5.20)\end{array}$ & $\begin{array}{l}18.20 \\
(5.26)\end{array}$ & $\begin{array}{l}13.25 \\
(5.12)\end{array}$ & $\begin{array}{c}6.20 \\
(4.79)\end{array}$ \\
\hline
\end{tabular}

Note: Figures in the parentheses are log transformed values: - : No population of PPFM, Initial population of PPFM in soil was: 5.50 x $104 \mathrm{cfu} / \mathrm{g}$ soil; DAT- Days after transplanting

Table.4 Influence of PPFM on disease severity and yield of chilli under field conditions

\begin{tabular}{|l|c|c|c|c|}
\hline \multicolumn{1}{|c|}{ Treatment details } & $\begin{array}{c}\text { Per cent fruit } \\
\text { rot infection }\end{array}$ & $\begin{array}{c}\text { Per cent } \\
\text { disease index }\end{array}$ & $\begin{array}{c}\text { Yield } \\
(\mathbf{q} / \mathbf{h a})\end{array}$ & $\begin{array}{c}\text { Capsaicin } \\
\text { content (\%) }\end{array}$ \\
\hline PPFM 6 & 44.00 & 55.00 & 2.55 & 0.16 \\
\hline PFM 170 & $(41.55)$ & $(47.87)$ & & $(2.29)$ \\
\hline PPFM 35 & 44.50 & 61.00 & 2.52 & 0.15 \\
& $(41.84)$ & $(51.35)$ & & $(2.22)$ \\
\hline PPFM Consortia & 47.00 & 65.00 & 2.20 & 0.14 \\
& $(43.28)$ & $(53.73)$ & & $(2.14)$ \\
\hline Reference strain of PPFM & 43.50 & 55.50 & 2.56 & 0.16 \\
\hline M. extorquens AM 1) & $(41.27)$ & $(48.16)$ & & $(2.29)$ \\
\hline Chemical control (Carbendazim) & 47.00 & 65.00 & 2.19 & 0.14 \\
& $(43.28)$ & $(53.73)$ & & $(2.14)$ \\
\hline Uninoculated control & 27.50 & 41.00 & 4.10 & 0.23 \\
\hline S. Em \pm & $(31.63)$ & $(39.82)$ & & $(2.75)$ \\
\hline CD $(\mathbf{0 . 0 5 )}$ & 50.00 & 69.00 & 1.86 & 0.13 \\
\hline
\end{tabular}

Note: Values in the parentheses are arc sine transformed values 


\section{Dynamics of PPFM population}

Variation in PPFM population was observed in rhizosphere and phyllosphere regions at different stages of crop growth. Higher population of PPFMs was recorded on phyllosphere as compared to rhizophere across treatments and stages. Lesser population of PPFM was recorded in different treatments $\left(5.60\right.$ to $13.13 \times 10^{4} \mathrm{cfu} / \mathrm{g}$ soil $)$ at initial stage of crop growth (30DAT), which increased later on at 60DAT (5.80 to $14.52 \times$ $10^{4} \mathrm{cfu} / \mathrm{g}$ soil) and 90DAT (6.1 to $15.15 \times 10^{4}$ cfu/g soil) and an drastic decline (5.25 to 8.93 $\times 10^{4} \mathrm{cfu} / \mathrm{g}$ soil) was observed at 130DAT in all treatments tested (Table 3). PPFMs population dynamics at phyllosphere followed the trend of rhizosphere except in uninoculated control at 90 DAT, the population of PPFMs found to decrease as compared to 60 DAT. Dynamics of PPFM population in rhizosphere and phyllosphere recorded at different plant growth stages showed highest population load on phyllosphere compared to rhizosphere. This could be directly related to the emission of methanol through stomatal openings during leaf expansion by pectin demethylation (Nemecek- marshall et al., 1995), which may be utilized by PPFMs to survive on the surface of leaves.

\section{Anthracnose incidence and yield}

Among different treatments imposed, spraying crop with carbendazim recorded least disease incidence (27.50\% FRI, 41.00 PDI) compared to other treatments (Table 4). In treatments involving PPFM isolates PPFM6 (44.00\% FRI, 55.00 PDI), PPFM170 (44.50\% FRI) and PPFM consortia (43.50\% FRI, 55.50 PDI) recorded least disease incidence compared to uninoculated control (50.00\% FRI, 69.00 PDI). PPFM consortia $(2.56 \mathrm{q} / \mathrm{ha})$ and PPFM6 (2.55 q/ha) provided higher yields compared to uninoculated control (1.86 q/ha) (Table 4). Carbendazim sprayed treatment plots recorded significantly higher yield $(4.10 \mathrm{q} / \mathrm{ha})$ compared to other treatments in the study. The pungency of chilli which is measured in terms of capsaicin content in different treatments varied from 0.13 to 0.23 per cent. The highest capsaicin content was recorded with carbendazim $(0.23$ $\%)$ treated plot. PPFM consortia $(0.16 \%)$ showed improved capsaicin content compared to uninoculated control $(0.13 \%)$. PPFM inoculated plants revealed lesser incidence of anthracnose disease compared to uninoculated control, nevertheless chemical control with carbendazim showed least disease incidence. Yield parameters like chilli yield and capsaicin content were directly proportional to anthracnose incidence in all the treatments studied. Though, carbendazim provided effective disease control, the environmental contamination and serious health risks in human beings outweigh its merits of disease control. Many studies have highlighted the potential risk to humans and undesirable impact on the environment by these agrochemicals (Jeyaratnam, 1981; Igbedioh, 1991; Forget, 1993) and even the risk of fungicide resistance at the standard dose of agrochemicals (Staub, 1991) is also reported which debits their potential disease control ability. On contrary, microorganisms as bioagents are ecofriendly and sustainable tools for effective disease management. Bioagents also helps to circumvent the contentious issue of chemical residues in export quality chilli.

In conclusion, performance of a plant growth promoting rhizobacteria (PGPR) under field conditions is a fundamental selection criterion for its identification as commercial biofertilizer. Selection based on their biocontrol efficiency as well as plant growth promotional ability will enable improved crop productivity. As bioagents are highly vulnerable to changing environment, expected results are often difficult to achieve with unpredictable weather (Bashan, 1998; Lucy et 
al., 2004). This is more so with the phyllosphere bioagents as they are subjected to highly varying weather vagaries compared to rhizosphere bioagents. The present study revealed that PPFMs are very good plant growth promoters with remarkable biocontrol efficiency against $C$. capsici under field conditions. PPFMs can be a valuable component of integrated disease management and sustainable chilli production, for which more efficient strains need to be identified and their compatibility with the different commercially available bioagents/chemicals needs to be worked.

\section{Acknowledgements}

Authors gratefully acknowledge the support and facilities provided by the concerned authorities at U.A.S., Dharwad, Karnataka for carrying out the present study. Financial assistance in the form of Senior Research Fellowship provided to First author by Indian Council of Agricultural Research, New Delhi is also gratefully acknowledged.

\section{References}

Bashan, Y. 1998. Inoculants of plant growthpromoting bacteria for use in agriculture. Biotechnol. Adv. 16, 729770.

Forget, G. 1993. Balancing the need for pesticides with the risk to human health. In: Forget G, Goodman T, de Villiers A, (Ed.), Impact of pesticide use on health in developing countries. IDRC, Ottawa: 2.

Holland, M.A. and Polacco, J.C. 1994. PPFMs and other covert contaminants: Is there more to plant physiology than just plant? Ann. Rev. Plant Physiol. Plant Mol. Biol. 45, 197-209.

Igbedioh, S.O. 1991. Effects of agricultural pesticides on humans, animals and higher plants in developing countries.
Arch. Environ. Health. 46, 218.

Indiragandhi, P., Anandham, R., Kim, K., Yim, W., Madhaiyan, M. and Sa, T. 2008. Induction of defense responses in tomato against Pseudomonas syringae pv. tomato by regulating the stress ethylene level with Methylobacterium oryzae CBMB20 containing 1aminocyclopropane-1-carboxylate deaminase. World J. Microbiol. Biotechnol. 24, 1037-1045.

Jackson, E.F., Echlin, H.L. and Jackson, C.R. 2006. Changes in the phyllosphere community of the resurrection fern, Polypodium polypodioides, associated with rainfall and wetting. FEMS Microbiol. Ecol. 58, 236-246.

Janahiraman,V., Anandham, R., Kwon, S.W., Sundaram, S., Pandi, V.K., Krishnamoorthy, R., Kim, K., Samaddar, S. and Sa, T. 2016. Control of wilt and rot pathogens of tomato by antagonistic pink pigmented facultative methylotrophic Delftia lacustris and Bacillus spp. Front Plant Sci. https://doi.org/10.3389/fpls.2016.

01626.

Jeyaratnam, J. 1985. Health problems of pesticide usage in the third world. $\mathrm{Br}$. Med. J. 42, 505.

Kim, K., Yim, W., Trivedi, P., Madhaiyan, M., Dekaboruah., H.P., Md. Rashedul Islam., Lee, G. and Sa, T. 2010. Synergistic effects of inoculating arbuscular mycorrhizal fungi and Methylobacterium oryzae strains on growth and nutrient uptake of red pepper (Capsicum annuum L.). Plant Soil, 327, 429-440.

Lakshmesha, K., Lakshmidevi, K., Aradhya, N. and Mallikarjuna S. 2005. Changes in pectinase and cellulase activity of Colletotrichum capsici mutants and their effect on anthracnose disease on Capsicum fruit. Arch. Phytopathol. Plant Prot. 38, 267-279. 
Lucy, M., Reed, E. and Glick, B.R. 2004. Applications of free living plant growth-promoting rhizobacteria. Antony Van Leeuwenhoek, 86, 1-25.

Madhaiyan, M., Poonguzhali, S., Senthilkumar, M., Sundaram, S., Heekyung, C., Jinchul, Y., Subbiah, S. and Tongmin, S. A. 2004. Growth promotion and induction of systemic resistance in rice cultivar Co-47 (Oryza sativa L.) by Methylobacterium spp. Bot. Bull. Acad Sinica, 45, 315-324.

Madhaiyan, M., Poonguzhali, S., Sundaram, S. P. and Tongmin S. A. 2005. A new insight into foliar applied methanol influencing phylloplane methylotrophic dynamics and growth promotion of cotton (Gossypium hirsutum L.) and sugarcane (Saccharum officinarum L.). Environ. Exp. Bot. 57, 168-176.

Madhaiyan, M., Suresh reddy, B.V., Anandam, R., Senthilkumar, M., Poonguzhali, S. and Sundaram, S. P. 2006. Plant growth promoting Methylobacterium induces defense responses in ground nut (Arachis hypogaea L.) compared with root pathogen. Curr Microbiol. 53, 270-276.

Mahadevan, A. and Sridhar, R. 1986. Methods in physiological plant pathology. $\quad\left(3^{\text {rd }}\right.$ Edn.), Sivakami Publications, Chennai (India).

Mayee, C. D. and Datar, V. V. 1986. Phytopatholometry, Technical Bulletin1. Marathwada Agriculture University, Parbhani, Maharashtra (India).

Muthuchelian, K., Paliwal, K., Gnanam, A. and Mitchel, R. K. 1990. The effect of three long chain aliphatic alcohols on photosynthesis and growth of Pennisetum polystachyeon schult. Photosynthetica, 24, 257-260.

Nemecek-marshall, M., MacDonald, R. C., Franzen, J. J., Wojciechowski, C. L. and Fall, R. 1995. Methanol emission from leaves: enzymatic detection of gas- phase methanol and relation of methanol fluxes to stomatal conductance and leaf development. Plant Physiol. 108, 1359-1368.

Panse, V. S. and Sukhatme, P. V. (1985). Statistical Methods for Agricultural Workers, ICAR, New Delhi (India).

Pyrlak, L. and Kose, M. 2009. Effects of plant growth promoting rhizobacteria on yield and some fruit properties of strawberry. J. Plant Nutr. 32, 1173-1184.

Radha, T. K., Savalgi, V. P. and Alagawadi, A. R. 2009. Effect of methylotrophs on growth and yield of soybean. Karnataka J. Agril Sci. 22, 118-121.

Ramachandran, N. and Rathnamma, K. 2006. Colletotrichum acutatum-a new addition to the species of chilli anthracnose pathogen in India, in Paper presented at the Annual Meeting and Symposium of Indian Phytopathological Society, Central Plantation Crops Research Institute (Kasaragod, Kerala, India).

Reddy, S. 2002. Studies on pink pigmented facultative methylotrophs as a new bioinoculant for groundnut (Arachis hypogea L.) M. Sc. (Ag.) Thesis submitted to Tamil Nadu Agriculture University, Coimbatore, Tamil Nadu (India).

Savitha, P. Sreenivasa, M. N. and Nirmalnath, J.P. 2015. In vitro screening for biocontrol activity of pink pigmented facultative methylotrophs against phytopathogens. Karnataka J. Agril Sci. 28, 286-287.

Savitha, P., Sreenivasa, M.N. and Nirmalnath, J. P. 2013. Production of plant growth hormones by pink pigmented facultative methylotrophs. J. Pure Appl. Microbiol. 7, 981-985.

Savitha, S., Santosh, H.B. and Sreenivasa, M.N. 2019. Assessment of Native Pink Pigmented Facultative Methylotrophs of Chilli (Capsicum annuum L.) for their 
Plant Growth Promotional Abilities. Int. J. Curr.Microbiol. Appl. Sci. 8, 11961205 .

Senthilkumar, M. 2003. Evaluating diazotrophic diversity and endophytic colonization ability Azorhizobium caulinodans and Methylobacerium species in bacterised and biotized rice. $\mathrm{Ph}$. D Thesis submitted to Tamil Nadu Agricultural University, Coimbatore, Tamil Nadu (India).

Staub, T. 1991. Fungicide resistance: practical experience and anti-resistance strategies and the role of integrated use. Ann. Rev. Phytopathol. 29, 421-442.

Sy, A., Giraud, E., Jourand, P., Garcia, N., Willems, A., de Lajudie, P., Prin, Y., Neyra, M., Gillis, M., Boivin-Masson, C. and Dreyfus, B. 2001. Methylotrophic Methylobacterium bacteria nodulate and fix nitrogen in symbiosis with legumes. J. Bacteriol.
$183,214-220$.

Thangamani, G. and Sundaram, S. P. 2005. Potential of facultative methylotrophs in increasing the yield of tomato crop. Abstract of Poster Presented in $3^{\text {rd }}$ Nation. Conf. Assoc. Appl. Microbiol. (IAAM), 10-12 January, 2005 Centre for Plant Biotechnology and Molecular Biology, College of Horticulture, Kerala Agricultural University, Thrissur, Kerala (India).

Wheeler, B. E. J. 1969. An introduction to plant diseases. John Wiley and Sons Ltd., London.

Yim, W., Woo, S., Kim, K. and Sa, T. 2012. Regulation of ethylene emission in tomato (Lycopersicon esculentum Mill.) and red pepper (Capsicum annuum L.) inoculated with ACC deaminase producing Methylobacterium spp. Korean J. Soil Sci. Fert. 45, 37-42.

\section{How to cite this article:}

Savitha Santosh and Sreenivasa, M. N. 2020. Field Evaluation of Native Pink Pigmented Facultative Methylotrophs for Growth Promotion and Anthracnose Management in Chilli. Int.J.Curr.Microbiol.App.Sci. 9(03): 718-726. doi: https://doi.org/10.20546/ijcmas.2020.903.086 